\title{
Rudolf Šrámek
}

Masarykova univerzita, Brno

\section{Aspekty „mikro" a ,makro" jako interpretační a klasifikační problém v onomastice}

\section{1. Úvod, nejednotnost definic}

Problematika aspektů „mikro” a „makro”, která z oblasti onomastické terminologie, ve které se objevila nejdř́íve, přerostla do oblasti klasifikace toponym, kde vyvolala (a dosud vyvolává) značné obtíže ne toliko v samém definování kategorie „mikro” a sekundárně i „makro”, ale především v teoretickém popisu jejich místa a funkce v propriálním systému jazyka. Avšak obecná onomastická teorie a rovněž terminologie onomastiky různých onomastických škol a center se této problematice bud' vyhýbají, nebo nedospěly dosud k žádnému přesvědčivému řešení. A proto ji do své interpretační, klasifikační a analytické práce včleňují s nejednotně definovaným či málo jasným významem. Ale nejčastější případ je ten, že tuto problematiku prostě ignorují a nevšímají si jí.

Tuto nežádoucí situaci vyvolává fakt, že v onomastice (a zvláště v teorii onomastiky) dosud nebylo zformulováno to nejhlavnější, totiž odpověd' na otázku, jaký typ (druh) propriálně pojmenovaného objektu nebo jevu a jeho propriálního pojmenování je třeba pokládat za „mikro” nebo „makro”. V nejnovější odborné literatuře pokládá [např. Seibicke 2004: 189] za mikronyma „Flur- und Gemarkungsnamen, Straßennamen, Gebäudenamen” a za makronyma mezi jiným „Meeres- und Flussnamen oder Gewässernamen und Siedlungsnamen oder Ortsnamen im engeren Sinne”. Liljana Dimtrovová-Todorová [2011: 248] definuje termíny makrooronim a makrochidronim jako име на голям планински (воден) обект a podle toho je pak př́znakem všech hesel s mikro- pochopitelně antonymní význam 'мальк'. Podobné pojetí je vyjádřeno v terminologickém slovníku ukrajinské onomastiky D. Bučka, N. Tkačovové [2012: 115, 121-122]: mikro-vymezují autoři sémanticky jako ‘малий, маленький, невеликий’ a antonymní makro- jako 'великий'. S takovou praxí se setkáváme v četných jiných publikacích. Vzniká proto otázka principiální důležitosti - jak rozumět atributům 'malý' a 'velký'1.

${ }^{1}$ Na toto téma se na 13. mezinárodním onomastickém kongresu ve Krakově 1978 rozvinula vzrušená diskuse, kterou se jeden renomovaný hydronomastiků pokusil ukončit téměř kuriózním návrhem, aby všechna jména vodních tokủ kratších než $50 \mathrm{~km}$ byla pokládána za mikrohydronyma. 


\section{Teoretické východisko interpretace}

Aspekty „mikro” a „makro” nepředstavují tedy jen pouhou antonymii dvou kategorií, které se sémanticky navzájem odlišují kvatitativním rozměrem. Jestliže je chceme interpretovat jako elementy proriálního systému jazyka, je třeba jejich opozici rozumět jako navzájem spjatý binární vztah, jako opozici spjatou binaritou. Jen tak může tento vztah v propriální sfére jazyka působit jako systémotvorný činitel a nikoli toliko jako činitel kvantitativního aspektu. Znamená to, že binarita „mikro” a „makro” musí nutně překročit kategorii kvantitativního rozměru a že musí mít charakter kategorie, která je schopna v propriální sfére jazyka působit systémotvorně, tzn. že musí plnit určité propriálně relevantní funkce. Redukce kategorí „mikro” a „makro” jen na aspekt kvatitativní takovou interpretaci neumožňuje. Funkční pojetí se opírá přinejmenším o dva znaky, které jsou pro moderní chápání onomastiky jako vědecké disciplíny zásadní. Ukazují: a) že propriální sféra jazyka je specifickou realizací systému jazyk vůbec, že onomastika je specifická subdisciplína lingvistiky a že propria jsou ,jazykovou” matérií; b) že propriální sféra jazyka představuje strukturně a funkčně uspořádaný celek, který má systémový charakter a plní takové specifické funkce, které apelativa realizovat nemohou.

\section{K historii termínu mikrotoponymum}

Rozpaky s chápáním nebo definicí elementu „mikro” a později i s jeho opozitní variantou „makro" trvají od dob, kdy se termín mikrotoponym(um) objevil poprvé. Měl francouzskou podobu microtoponyme a byl použit $v$ referátu Paula Lebela na Prvním mezinárodním kongresu toponymie a antroponymie v r. 1938 v Paříži, a to kupovidu v kontextu antroponomastickém [Lebel 1938: 92-96]. Tento termín i od něho odvozený termín microtoponymie se ve francouzské onomastice rychle ujal, což svědčí o potřebě termínu pro ten druh toponym, která se v němčině tradičně nazývala (a dosud nazývaji) Flurnamen, př́ípadně Gemarkungsnamen, a která v češtině měla už od r. 1860 terminologické označení pomistní jméno². Dosti staré jsou termíny obsahující ve své první části jiné motivické elementy: nizozemské (1864) veldnaam, akkernaam, landnaam, angličtina zná od poloviny 19. století termín minor names, od 1925 také field names. Ve Skandinávii se termín mikrotoponym s překladem elementu ,mikro-” objevil nejprve r. 1920 v Dánsku v podobě smaa Stednavn „malá místní jména”, poněkud později v Norsku jako smaanavne

${ }^{2}$ Vytvořil je historik Hermenegild Jireček [1860/1861]. Terminologické stránce výzkumu vlastních jmen byla v české onomastice věnována vždy velká pozornost. Podrobnosti viz v kn. Olivová-Nezbedová, L. Knappová, M. Malenínská, J. Matúšová [2005], a v Słowańska onomastyka. Encyklopedia I [Rzetelska-Feleszko, Cieślikowa, Duma 2002: 83-84]. 
„malá jména”3. Jak vidět, význam „mikro” se pro vznik pojmenování „mikrotoponym" stal už tehdy pojmenovacím motivem. Termín mikrotyponym(um) se však v 60. letech 20. století rozšiŕil zcela neočekávanou cestou. Jak píše N. V. Podol'skaja [1975: 85-95], objevil se na první onomastické konferenci SSSR konané v Kyjevě v r. 1959 a odtud se prý počal šírit ve slovanské onomastice. Tvrzení N. Podol'ské však není zcela přesné. Termín mikrotoponymum se neujal v toponomastice české a slovenské, $v$ chorvatštině byl znám již dřive jako přejetí z francouzského nebo italského prostředí. Poměrně rychle se však - kromě ve východoslovanském prostředí - rozšiŕíl v bulharštině. Polská onomastika představuje speciální případ. Nejprve začal koexistovat s termíny nazwy fyzjograficzne nebo nazwy terenowe; např. W. Śmiech [1982] napsal důležitou stat' o celopolské kartotéce „,nazw terenowych Polski”, A. Wolf, E. Rzetelská-Feleszková vydali metododologicky vzornou monografii o „nazwach terenowych” na Mazovsku [1982]. Ale paralelně s tím uveřejňuje v r. 1983 M. Kornaszewski knihu o dolnolužické „mikrotoponymii”. Termín mikrotoponymum se v polské onomastice postupně rozšíril především ve studiích teoretických, v nichž se už jako samožrejmost vyskytují i další termíny odvozené, např. mikrotoponomastyka, mikrotoponomastykon, mikrotoponomastyczny [viz např. Mrózek 1990; 2008]. Takovou terminologickou specifikaci možno pozorovat např. i v onomastice rakouské, částečně i německé: materiálové práce analyzují Flurnamen, teoretické Mikrotoponyme.

Termín mikrotoponymum však rychle zakotvil v onomastice v bývalé NDR, a to především v převáženě slavisticky orientované lipské onomastické škole, kde také vznikla v tomto smyslu reprezentativní monografie H. Naumanna [1972]. Avšak už tehdy se vůči termínu vyskytly i výhrady [Witkowski 1995: 288-294], které v některých aspektech trvají dodnes [Zschieschang 2007: 413-420]. Pozoruhodné je, že se termín Mikrotoponym téměř neobjevil v tehdejší onomastice západoněmecké, rakouské a švýcarské. Ve sborníku z významného Gießener Flurnamen-Kolloquium [Schützeichel 1984] se vyskytuje jen jednou, sborník Mikrotopyme [Meineke, Tiefenbach 2011], vzniklý ze stejnojmenného sympozia konaného v Jeně 2009, má ho sice programově doložen v titulu, ale kromě příspěvků R. Rentenaara [2011: 197-205] a E. Windberger-Heidenkummerové [2011: 286-300] je běžný jen termín Flurnamen. Vynikající studii o mikrotoponymech publikovala Rakušanka E. Windberger-Heidenkummerové [2001]. Tato práce patří svou obecně teoretickou koncepcí a funkčním pojetím k nejlepším dílů současné teoretické onomastiky. Výsledky rozporuplných diskusí, které ve slovanské onomastice doprovázely názory na termín mikrotoponym(um), se odrazily v první celoslovanské kodifikaci onomastické terminologie [OC 1983]. Termín se uvádí jen v materiále ruském, srbocharvátském a makedonském.

Po tomto krátkém ,historickém” exkurzu navazujeme na obsah první kapitoly.

${ }^{3}$ Pramenem informací je vynikající studie Roba Rentenaara [2011: 197-205], obsahující velmi cenné poznatky teoretické. 


\section{Analýza aspektu „mikro" a ,makro"}

4.1. Jak bylo v úvodní části naznačeno, elementy „mikro” a „makro” samy o sobě se svými kvantitativními významy nepředstavují takové kategorie, které by mohly mít $\mathrm{v}$ onymii a v celé propriální vrstvě jazyka povahu systémotvorných činitelů. Základní úlohou elementů „mikro” a „makro” totiž je 'být prŕíznakem' (pol. nacechowaniem) jiných propriálně relevantních jevů (kategorií, systémových vlastností). Ukáže to prríklad: 'Mikrotoponymum' Za mlýnským potokem není propriem (= není prvkem propriální sféry jazyka) proto, že pole takto pojmenované a ležící za potokem, který poháněl kdysi kola blízkého mlýna, je svým fyzickým rozměrem malé. Element „mikro”, vyjadřující kvantitativní rozměr, nemůže být sám o sobě nositelem a manifestací kategorie propriality, a proto nemůže rozhodovat o tom, že nějaké pojmenování je propriem, že nějaký nominační proces je procesem, který se realizuje v propriální sféře jazyka. Pomístní jméno (pol. nazwa terenowa) Za mlýnským potokem je propriem proto, že představuje strukturovaný nominační celek, který reprezentuje určitý propriálně pojmenovací akt (názvotvorný) model, a který bez ohledu na příznaky „mikro” nebo „makro” plní v lokální komunikaci tři základní funkce, specifické jen pro propria a nikoli pro apelativa. Jsou to funkce individualizující (singularizující), identifikační, diferenciační a lokalizující [Šrámek 1989: 367-374; 1999: 22-34; 2007: 45-57, v užším vztahu k „mikrotoponymii” 2010: 125-135]. Znamená to, že proprium Za mlýnským potokem porpriálně pojmenává to a to pole, individualizuje je, identifikuje je jako to a to místo a tím je diferencuje od jiných míst, od jiných objektů, a lokalizuje je tam a tam. Př́źznak „mikro” se proto na názvotvorném procesu ani motivicky, ani lexikálně nebo derivačně neúčastní. A přesto je vícelexémové pojmenování Za mlýnským potokem vlastním jménem.

4.2. Jaká tedy vlastně je role př́znaku „mikro”? Vznik proprií má svou mimojazykovou příčinu. Je vyvolán společnou potřebou v komunikaci pojmenovat a identifikovat nějaký objekt nebo nějaký jev jako jednotlivinu. Tato potřeba se sice realizuje pomocí jazykových prostředků, ale inicujícím momentem vzniku i užívání propria je vždy konkrétní komunikační situace. A právě komunikační situace je ten faktor, který umožňuje, aby se v propriální sfére jazyka (v propriálním systému jazyka) elementy „mikro” nebo „makro” uplatnily jen v kombinaci s kategorií 'proprialita'. Jedině tak se může stát, že proprium Za mlýnským potokem je „nacechowane” př́znakem „mikro” nikoli pro eventuální malou fyzickou podobu pojmenovaného objektu (= pole, louky za mlýnským potokem), ale proto, že žije v malém okruhu uživatelů, že jeho komunikační rádius je lokálně omezen jen na ty uživatele, kteří toto jméno v každodenním životě potřebují a pro které plní propriální funkce. Specifičnost takové komunikační situace netvoří „,mikrovelkost” (kvantitativní rozměr) pojmenovaného objektu, ale „mikroužívání”, tj. působení propriálních funkcí na oemezenou, ohraničenou „mikrokomunikačni” situaci. Komunikační rádius je ohraničen malým, zpravidla vesnický okruhem 
uživatelů. Tento rádius může ovšem být z mimojazykových přičin u různých jmen různě velký a intenzivní - od lokálního až k familiárnímu a individuálnímu. Proprium Za mlýnským potokem je proto „doma”, žije a užívá se jen v jedné lokalitě, jen $v$ jedné vsi. $Z$ hlediska funkčního můžeme tento fakt formulovat také tak, že akční rádius užívání a funkce propria Za mlýnským potokem se realizuje jen v konkrétním ohraničeném (omezeném) komunikačním prostředí a že je orientován vždy introvertně na lokálně omezený typ propriálního systému. Toto pojetí má dva důležité důsledky: a) analýza, klasifikace včetně typologické interpretace celého systému pomístních jmen (= systemu nazw terenowych) nějakého jazyka musí být výsledkem abstrakce vzniklé na základě sítě (nebo mozaiky) lokálních „mikrosystémů”. Vyskytuje-li se mikrotoponymum Za mlýnským potokem ve více vsích, je z propriálního hlediska pokaždé jiným propriem; b) proti introvertní orientaci ‘mikrotoponym' stojí extrovertní funkční orientace toponym sídlištních (oikonymických) objektů; jsou totiž součástí komunikačního prostředí nadlokálního, tj. regionálního, celostátního apod.

Paralelní případ představují hypokoristika. Jejich základním akčním rádiem je rodinné nebo príbuzenské prostředí. Hypokoristika, kterých se užívá doma nebo v jiném omezeném komunikačním okruhu, jsou vlastně 'mikroantroponyma'. Mikroantroponymický systém nějakého jazyka pak nevzniká jako mechanická sumarizace jednotlivých lokálních (famililiárních, individuálních, regionálních) mikrosystémů, ale jako abstrakce společných názvotvorných způsobů, typů a znaků.

Jak vidět, příznaky „mikro” a „makro” nejsou vázány na konkrétní druhy proprií. Jsou však vázány na typy konkrétních komunikačních situací, ve kterých se proprií užívá, popř. ve kterých se tvoří. A proto nelze „mikro” a „makro” definovat numericky.

\section{Získané poznatky}

Analýza role funkce elementů „mikro” a „makro”, kterou jsme podali, umožňuje ve velmi zobecněné a abstrahované podobě formulovat následující strukturu poznatků, které zasahují jak do systematiky obecné onomastické teorie (včetně terminologie), tak do interpretační a klasifikační praxe onomastiky: 1. a) elementy „mikro" a sémanticky antonymní „makro-” mají v systému jazyka charakter a funkci příznaku a v propriální sfére jazyka nejsou samy o sobě nositeli propriality; b) oba příznaky jsou navzájem propojeny jako binárně fungující opozice; c) př́znaky „mikro” a „makro” se manifestují v užívání propríí v nespecifických komunikačních situacích a mohou se odrazit v tvoření proprií. 2. Oba prŕznaky jsou elementy kombinatorní a spojují se s takovými kategoriemi, které jsou v propriální sfére jazyka nositeli nebo výrazem jejího systémového charakteru. Jsou to: a) na úrovni propriálně pojmenovávaných objektů a jevů (neboli na úrovni mimojazykových elementů) mohou, ale nemusejí oba elementy být 
vyjádřením př́iznak kvantitativních vlastností, tj. malosti nebo velikost objektu. Přesto, že toto kritérium, vázené na kvantitativní rozměr pojmenovaného objektu, může být značně nespolehlivé, protože je silně individuální a subjektivní, a proto často i neobjektivní, nacházejí elementy „mikro” a „makro” v současné onomastice uplatnění. Onomastická praxe se tak zcela nekryje s požadavky onomastické terminologie; b) na úrovní pojmenovacího systému označují elementy „mikro" a „makro” pozici v systému, např. při analýze takových kategorií jako jsou produktivity a frekvence, elementy struktury propria, rozměr areálového rozšíření apod.; srov. termíny makrotyp ${ }^{4}$, makroareál, mikrotyp ${ }^{5}$, minisystém atd. S charakterem propriálního areálu jako „obrazu” propriálně systémového jevu počítá i Seibicke [2004: 185-212]; c) na úrovni propriálního úzu v komunikaci se př́znak „mikro-” spojuje především s omezeným rozměrem komunikační situace a s tzv. introvertní funkcí. ${ }^{6} ;$ d) specifický problém představuje problém kodifikace termínů s mikro- a makro-. Úsilí odborných terminologických komisí nepřineslo zatím obecně přijímané řešení.

\section{Závěr}

Naše úvaha nad pozicí a funkcí elementů „mikro” a „makro” by však v žádném př́padě neměla vyvolat dojem pesimistického stanoviska. Vždyt's oběma elementy se v onomastice, zvl. v onomastické teorií setkáváme stále častěji. Znamená to, že se „mikro-” a „makro-” stávají součástí terminologického aparátu. Schází však zatím stabilita v definování toho, co znamenají, jakých propriálně relevantních jevi̊ se týkají a jaká je jejich systémotvorná hodnota. K stejnému závěru dospěl i přední představitel současné onomastiky Friedhelm Debus [2012: 27]: „Es ist klar, dass... das Kriterium der einwandfreien Abgrenzung der Eindeutigkeit... nicht gegeben ist. Gleichwohl hat sich die entsprechende Terminologie eingebürgert".

\section{Bibliografie}

Bučko Dmitro, Tkačova Natalita, 2012, Словник украӥнької ономастичної термінологї, Харків. Debus Friedhelm, 2012, Namenkunde und Namengeschichte. Eine Einführung, Berlin.

Dimitrova-Todorova Liljana, 2011, Собствените имена в България, София.

${ }^{4}$ Termín se dobře ujal v onomastice polské, srov. četné práce H. Górnowicza, S. Rosponda, H. Borka aj.

${ }^{5}$ Poučný je tento př́iklad: objevná teorie „malých typů”, která byla formulována Vladimírem Šmilauerem [1958: 41-51], nebyla nazvána „teorie mikrotypư”. Prof. Šmilauer pokládal termíny s mini- za novější, neustálený [Šmilauer 1963: 8].

${ }^{6}$ O introvertní a extrovertní funkci viz Rudolf Šrámek [2010: 125-135]. 
HSK = Eichler Ernst, Hilty Herold, Löffler Heinrich, Steger Hugo, Zgusta Ladislav (eds.), Namenforschung - Name Studies - Les noms propres. Ein internationales Handbuch zur Onomastik, Berlin-New York, 1. Bd. 1995, 2. Bd. 1996, 3. Bd. 1996.

Jireček Hermenegild, 1860/1861, Naše pomístné názvy, „Památky archeologické a místopisné”, roč. 4 , oddíl 1, 91 .

Kornaszewski Marek, 1983, Nazwy zestawione w dolnoluzyckiej mikrotoponimii powiatu chociebuskiego, Poznań.

Lebel Paul, 1938, L'énquête bourguignonne sur les lieux-dits et les anthroponymes, [in:] Premiér Congrès International de Toponymie et d'Anthroponymie. Actes et Mémoires. Paris, 25-29 Juillet, Paris, 92-96.

Meineke Eckhard, Tiefenbach Heinrich (eds.), 2011, Mikrotoponyme. Jenaer Symposion 1. und 2. Oktober 2009, Heidelberg.

Mrózek Robert, 1990, System mikrotoponimiczny Ślaska Cieszyńskiego XVIII wieku, Warszawa.

Mrózek Robert, 2008, Diachroniczny mikrotoponomastykon w postulatywnym ujęciu badawczym, „Acta onomastica” IL, 240-250.

Naumann Horst, 1972, Die bäuerlichen deutsche Mikrotoponymie der meißnischen Sprachlandschaft (Deutsch-Slawische Forschungen zur Namenkunde und Siedlungsgeschichte 30), Berlin.

ОC, 1983, Основеи систем и трминологија на словенската ономастика. Основная система и терминогия славянской ономастики. Grundsystem und Terminologie der Slawischen Onomastik, Skopje.

Olivová-Nezbedová Libuše, Knappová Milena, Malenínská Jitka, Matúšová Jana, 2005, Pomístní jména v Čechách. O čem vypovídaji jména poli, luk, lesì, hor, vod a cest, Praha.

Podol'skaja Natalija Vasiljevna, 1975, Russische onomastische Terminologie, [in:] Ernst Ernst, Wolfgang Fleischer, Aleksandra V. Superanskaja (eds.), Sowjetische Namenforschung, Berlin.

Rentenaar Rob, 2011, Mikrotoponymie aus nordwestgermanischer Sicht. Einige Bermerkungen zur Definition und Terminogie, [in:] E. Meineke, H. Tiefenbach (eds.), 197-205.

Rzetelska-Felszko Ewa, Cieślikowa Aleksandra, Duma Jerzy (eds.), 2002, Stowiańska onomastyka. Encyklopedia, t. I, Warszawa-Kraków.

Schützeichel Rudolf (ed.), 1984, Gießener Flurnamen-Kolloquium 1.-4. Oktober 1984 Heidelberg („Beiträge zur Namenforschung”, Neue Folge, Beiheft 23).

Seibicke Willfried, 2004, Areallinguistiche Methoden der Namenforschung, [in:] Andrea Brendler, Silvio Brendler (eds.), Namenarten und ihre Erforschung. Ein Lehrbuch für das Studium der Onomastik, Hamburg.

Śmiech Witold, 1982, Stownik nazw terenowych Polski, „Onomastica” XXVII, 161-173.

Šmilauer Vladimír, 1958, Metota „malých typů” v toponomastice, [in:] Sborník slavistických pracivěnovaných IV. mezinárodnímu sjezdu slavistku v Moskvě, Praha.

Šmilauer Vladimír, 1963, Úvod do toponomastiky, Praha.

Šrámek Rudolf, 1989, Onymische Funktion und funktionale Namenforschung, [in:] Svante Strandberg (ed.), Studia onomastica. Festskrift till Thorsten Anderson, Stockholm, 367-374. Přetisk in: Šrámek Rudolf, Beiträge zur allgemeinen Namentheorie, Wien 2007, 64-71.

Šrámek Rudolf, 1999, Úvod do obecné onomastiky, Brno.

Šrámek Rudolf, 2007, K funkčním opozicím v onomastice, „Наукові запискі. Мовознавство” 1 (16), 45-57.

Šrámek Rudolf, 2010, Zur Typologie der Flurnamen, [in:] Hubert Bergmann, Peter Jordan (eds.), Geographische Namen - Vielfalt und Norm. 40 Jahre institutionalisierte Namenforschung und - standardisierung in Österreich. 65. Geburtstag von Isolde Hausher, Wien, 125-135.

Windberger-Heidenkummerové Erika, 2001, Mikrotoponyme im sozialen und kommunikativen Kontext, Frankfurt am Main (= Schriften zur deutschen Sprache in Österreich 30). 
Windberger-Heidenkummer Erika, 2011, Kontiuität und Diskontunität von Flurnamen. Probleme und Beispiele, [in:] Eckhard Meineke, Heinrich Tiefenbach (eds.), 289-306.

Witkowski Teodolius, 1995, Probleme der Terminologie, viz HSK, 1. Bd.

Wolf Armin, Rzetelska-Feleszko Ewa, 1982, Mazowiecke nazwy terenowe do końca XVI wieku, Warszawa.

Zschieschang Christian, 2007, Ökonomische Aspekte in der Mikotopnymie an der mittleren Elbe, [in:] Ludger Kremer, Elke Ronneberger-Sibold (eds.), Names in Commerce and Industry: Past and Prezent, Berlin.

\author{
Rudolf Šrámek
}

\title{
The „micro" or „macro" aspects as the interpretation and classification challenge in onomastics
}

\section{(Summary)}

Onomastic studies performed in various research centres either avoid the "micro" or "macro" topics both from the theoretical and terminological aspects, or they have not yet come to any convincing solution. So far, all attempts to find the unequivocal definition have failed. Until today, no clear statement that would answer the core question about "what type of the proprial object and its naming process" should fall under "micro" or "macro" categories exists. Let's assume that the "micro" and "micro" aspects do not have any relation to any quantitative or physical dimension. Regardless of its "micro" or "macro" aspects, the field name Za mlýnským potokem (Behind the mill's brook) is a proprium because as a proper name it fulfils the following basic functions in the local communication that are distinctive for propria, and not for appellatives: individualisation, identification, differentiation and localisation. The use and the functions are determined by the specific communication framework (i.e. the actual communication activity), and are exclusively focused on the local proprial system. The particular communication circumstances are of the primary importance for the "micro" and "macro" aspect definition.

Slowa kluczowe: onomastyka, teoria nazewnictwa, aspekty „mikro” i „makro”. Key words: onomastics, theory of onomastics, "micro" and "macro" aspects. 